\title{
An increase in the burden of neonatal admissions to a rural district hospital in Kenya over 19 years
}

\author{
Michael K Mwaniki ${ }^{*}$, Hellen W Gatakaa', Florence N Mturi', Charles R Chesaro', Jane M Chuma', \\ Norbert M Peshu1, Linda Mason², Piet Kager ${ }^{3}$, Kevin Marsh $^{1,4}$, Mike English 1,4, James A Berkley ${ }^{1,5}$, \\ Charles R Newton ${ }^{1,6,7}$
}

\begin{abstract}
Background: Most of the global neonatal deaths occur in developing nations, mostly in rural homes. Many of the newborns who receive formal medical care are treated in rural district hospitals and other peripheral health centres. However there are no published studies demonstrating trends in neonatal admissions and outcome in rural health care facilities in resource poor regions. Such information is critical in planning public health interventions. In this study we therefore aimed at describing the pattern of neonatal admissions to a Kenyan rural district hospital and their outcome over a 19 year period, examining clinical indicators of inpatient neonatal mortality and also trends in utilization of a rural hospital for deliveries.
\end{abstract}

Methods: Prospectively collected data on neonates is compared to non-neonatal paediatric ( $\leq 5$ years old) admissions and deliveries' in the maternity unit at Kilifi District Hospital from January $1^{\text {st }} 1990$ up to December $31^{\text {st }}$ 2008, to document the pattern of neonatal admissions, deliveries and changes in inpatient deaths. Trends were examined using time series models with likelihood ratios utilised to identify indicators of inpatient neonatal death.

Results: The proportion of neonatal admissions of the total paediatric $\leq 5$ years admissions significantly increased from 11\% in 1990 to 20\% by 2008 (trend 0.83 (95\% confidence interval $0.45-1.21$ ). Most of the increase in burden was from neonates born in hospital and very young neonates aged $<7$ days. Hospital deliveries also increased significantly. Clinical diagnoses of neonatal sepsis, prematurity, neonatal jaundice, neonatal encephalopathy, tetanus and neonatal meningitis accounted for over $75 \%$ of the inpatient neonatal admissions. Inpatient case fatality for all $\leq 5$ years declined significantly over the 19 years. However, neonatal deaths comprised 33\% of all inpatient death among children aged $\leq 5$ years in 1990 , this increased to $55 \%$ by 2008 . Tetanus $256 / 390$ (67\%), prematurity 554/1,280 (43\%) and neonatal encephalopathy $253 / 778(33 \%)$ had the highest case fatality. A combination of six indicators: irregular respiration, oxygen saturation of $<90 \%$, pallor, neck stiffness, weight $<1.5 \mathrm{~kg}$, and abnormally elevated blood glucose $>7 \mathrm{mmol} / /$ predicted inpatient neonatal death with a sensitivity of $81 \%$ and a specificity of $68 \%$.

Conclusions: There is clear evidence of increasing burden in neonatal admissions at a rural district hospital in contrast to reducing numbers of non-neonatal paediatrics' admissions aged $\leq 5$ years. Though the inpatient case fatality for all admissions aged $\leq 5$ years declined significantly, neonates now comprise close to $60 \%$ of all inpatient deaths. Simple indicators may identify neonates at risk of death.

\section{Background}

Each year close to four million newborns die world wide $[1,2]$. Over $98 \%$ of these deaths occur in developing nations with the highest rates in Africa [3]. Many more

\footnotetext{
* Correspondence: mmwaniki@kilifi.kemri-wellcome.org

${ }^{1}$ Centre for Geographic Medicine Research (Coast), Kenya Medical Research Institute, PO Box 230, Kilifi, Kenya

Full list of author information is available at the end of the article
}

newborns who survive have brain insults, resulting in severe disabilities such as convulsive disorders, cerebral palsy and cognitive impairments, thus adding further burden to healthcare, social systems and the home environment [4-7].

Over the last two decades sustained resources and effort have been put into prevention and reduction of morbidity and mortality of children aged $\leq 5$ years. Some

\section{Biomed Central}


of the key areas that have received widespread attention include increasing and sustaining immunisation coverage, introduction of new vaccines for invasive bacterial diseases (haemophilus and pneumococcal infections) and strategies aimed at prevention and development of effective treatment for falciparum malaria [8-11]. These interventions have largely benefited the older child ( 2 to 60 months) and it is thought mortality in this group may have halved in some areas [1], particularly with the reduction of certain diseases such as malaria and pneumonia [10-13].

Contrary to the encouraging trend in the older child, neonatal morbidity and mortality remains unacceptably high [1-3], with nearly $40 \%$ of the annual global deaths in children aged $\leq 5$ years occurring during the neonatal period [14]. This presents a major obstacle in achieving the aspirations of the fourth millennium development goal of reducing under five mortality by two thirds by the year 2015 in most of the resource poor nations [15]. Paradoxically, despite the fact that these countries have the highest rates of neonatal deaths, there are no published studies demonstrating trends in neonatal admissions and outcome in rural health care facilities in resource poor regions. This issue was highlighted by the World Health Organization (WHO) concerns that neonatal morbidity and mortality rates have largely not been measured long enough to reach reliable conclusions on trends [14]. Such information is critical in planning public health interventions. Importantly, the ability to recognize neonates with potentially life-threatening illness warranting urgent medical attention at presentations to rural health facilities is thought to be critical in reducing mortality [3]. However, current guidelines to recognise such neonates are largely based on data from the WHO young infant study of the early $1990 \mathrm{~s}$ [16-18]. A major limitation of this study is that it did not include the first week of life, where most of the neonatal deaths occur.

Therefore, given the paucity of information outlined, we describe trend in neonatal admissions and outcome to a district general hospital in a Kenyan rural area over a 19-year period, and further examine indicators of inpatient neonatal deaths.

\section{Methods}

Site

This study was done at Kilifi District Hospital (KDH) on the coast of Kenya. The hospital is located in a malaria endemic area and serves a population of over 500,000 people [19], but $80 \%$ of the admissions come from an area with 260,000 inhabitants. The hospital has a 40-bed general all purpose paediatric ward with designated areas for nursing various disorders such us acute conditions, paediatric surgery, burns, diarrhoeal diseases, malnutrition and neonatal conditions. In addition the hospital has a 40-bed maternity facility. Newborns delivered with complications or who fall ill post delivery are transferred to the neonatal bay. Likewise neonates born at home and brought to the hospital if ill are admitted in the neonatal bay if thought to be severely unwell. A high dependency unit ( 6 beds) exists where very severely sick children are managed. Available interventions in the general paediatric ward and the high dependency unit include oxygen, intravenous fluids, antibiotics, phototherapy, exchange transfusion, and nasogastric tube feeding, but not parenteral nutrition, mechanical ventilation or umbilical arterial catheterization. Though the hospital is a district level health facility, very few cases are referred (mainly complex surgical cases) to the provincial hospital. Consent for use of the data was obtained from the guardian of every individual child at point of admission, and the study was approved by Kenyan National Scientific and Ethical Review Board.

\section{Data collection \\ Pediatric data}

At $\mathrm{KDH}$, a prospective surveillance system of all paediatric admissions has been in place since 1989. Based on this system, several studies on malaria, lower respiratory tract infections, malnutrition and neonatal conditions, amongst others, have been published [20-22]. On admission and at discharge or death, standardized clinical and laboratory data are collected.

For this study we examined all the admission data collected from January $1^{\text {st }} 1990$ to December $31^{\text {st }} 2008$. Where specific data were not collected during the entire period, we examined these data from the time such information was available, and used the admissions during this period as the denominator. Trend analysis, was done on data that were available for at least 5 consecutive years.

\section{Maternity delivery data}

In contrast to the paediatric ward, the hospital maternity ward record keeping was not computerized. All deliveries are recorded manually in the maternity inpatient record book supplied by the Kenyan Ministry of Health, from which we extracted the data for the study period.

\section{Study population}

We utilised data collected from all neonates (age $\leq 28$ days at admission) [23] and non-neonatal paediatric admissions aged $\leq 5$ years admitted to the hospital during the study period. Sick neonates admitted to the hospital after delivery at home were considered as outborn. Those delivered either in the district hospital or any other health facility and referred to the ward in case of ill-health were considered to be hospital births or inborn. Data extracted included:-i) Age and place of birth. ii) Clinical Presentation and examination findings: 
complaints: fever, cough, convulsion, diarrhoea, vomiting, jaundice, hypoxemia, respiratory distress, impaired consciousness, agitation, bulging fontanel and impaired perfusion. iii) Clinical diagnostic syndrome: admission discharge diagnoses recorded as: birth asphyxia, prematurity, neonatal sepsis, meningitis, neonatal jaundice and neonatal tetanus. iv) Laboratory investigations: culture results, full blood count, blood glucose. v) Outcome at discharge: dead or alive.

\section{Formulation of clinical diagnoses}

Routinely, all paediatric admissions to our centre are reviewed at admission, and then at least daily till discharge or death by clinicians under close supervision of a consultant paediatrician. Diagnoses of neonatal sepsis, neonatal encephalopathy, prematurity, meningitis, neonatal tetanus and neonatal jaundice were made after review of admission history, inpatient management notes and laboratory investigations at point of discharge. These diagnoses follow recognized guidelines for management of common illness with limited resources [24]. A diagnosis of invasive bacterial disease (IBD) was made on isolation of a pathogenic organism from sterile sites (blood or cerebrospinal fluid). Blood cultures were done on all neonates admitted from 1998. We therefore looked at trend in positive cultures from that date onward. Sepsis was also considered as the possible diagnosis in any newborn presenting with abnormal temperature $\left(<36.0^{\circ} \mathrm{C}\right.$ or $>37.5^{\circ} \mathrm{C}$ ), multiple skin pustules, redness or pus discharge from the umbilicus, respiratory distress, convulsions and feeding problems. A diagnosis of neonatal jaundice was made when total serum bilirubin levels (as measured by the Neobil, Schuco International, Lyndhurst avenue London) were elevated above the threshold requiring phototherapy for the age, gestation and presenting clinical signs of the newborn [25]. Neonatal tetanus was considered in any newborn presenting with trismus or spasms occurring on stimulation or spontaneously, with or without feeding difficulties. Prematurity was considered in any neonate born before 37 completed weeks of gestation if the last monthly period was known. However where this was not known, the gestation at delivery was estimated by the admitting clinician using a simplified criteria that took into account; the head circumference, mid-upper arm circumference, breast size, ear form, gentalia, and skin texture [26]. Due to limitations of monitoring of labour in most deliveries at home and even in hospitals in resource poor settings, diagnosis of neonatal encephalopathy largely relies on history and clinical examination. Therefore, a diagnosis of neonatal encephalopathy was considered in any newborn where a difficult delivery was reported with accompanying history and signs of a poor cry, convulsions, coma, irritability and abnormal muscle tone.

\section{Statistical considerations}

Data were entered at admission and discharge using a FileMaker Pro database (5.5v1 Developer, FileMaker Inc, USA). We used Stata 9.2 (StatsCorp, Tx, USA) for the final analysis. Total cases of neonatal admissions and neonatal admissions by final clinical diagnosis were assembled chronologically by admission year and total non-neonatal admissions similarly assessed. They were initially examined using time series regression analysis models. A continuous variable indicating time in years from the start of observations was included in the models. The coefficient of time in the models estimates the trend in the series (the year-to-year change). A P-value $<0.05$ was considered significant. Likewise, we evaluated the trend in the proportions of neonatal admissions to total paediatric admissions and also examined the trend in annual maternity deliveries at the hospital. Initially we analyzed the overall neonatal admission trend for the entire 19-year period. However, from the year 2000, information about the place of delivery of all newborn admissions was systematically collected. Therefore we further analyzed the two periods (1990 to1999) and (2000 to 2008) separately.

Several assumptions are used in ordinary least square analysis [27]. These assumptions are almost always violated by longitudinal data $[28,29]$. We therefore used a Durbin-Watson statistic to test for serial autocorrelation that showed there were minimal (non-significant) serial autocorrelations in the raw neonatal and non-neonatal datasets (Durbin's alternative test for autocorrelation P $=0.29 \& 0.15$, respectively). To further correct for any autocorrelation and possible heteroscedasticity, the Prais-Winston command specifying the Cochran-Orcutt ssesearch option was used in the regression models. Differences in proportions were examined using a $\chi^{2}$ test.

In order to delineate factors associated with inpatient neonatal death, likelihood ratios (LR) were used. LR are less likely to change with prevalence of a disorder than sensitivity and specificity and may be used to combine results from multiple tests [30]. For this purpose, data from 2000 to 2008 were used because all the variables of interest were available from that period. Initially we examined the crude positive (PLR) and negative (NLR) likelihood ratios for neonatal death of each clinical indicator. Indicators with crude likelihood ratios $\geq 2.0$ or $\leq 0.5$ were considered potentially independent. These were then adjusted for the confounding effects of other variables in multivariate analyses using the method of Speigelhalter and Knill-Jones [31]. Thirdly practical prediction rules for inpatient neonatal deaths using indicators with adjusted likelihood ratios of $\geq 2.0$ or $\leq 0.5$ in multivariate analysis were constructed. Finally, we evaluated the ability of the final rules to predict inpatient 
neonatal death with a receiver operating curve (ROC). We have previously described this approach $[32,33]$.

\section{Results}

There was a marked increase in the burden of neonatal admissions (fig1), with the total annual number of neonatal admissions significantly increasing by $211 \%$ from 240 cases in 1990 to 759 cases in 2008 (trend 34.68 (95\% CI 25.60-37.76, t-stats 11.05, $\mathrm{p}<0.001)$ ). The proportion of neonatal admissions to total paediatrics admissions aged $\leq 5$ years increased from $11 \%$ in 1990 to $20 \%$ by 2008 . This was significant (trend 0.83 (95\% CI 0.45 - 1.2 , t-stats $4.63, \mathrm{p}<0.001$ ) and remained significant even after correcting for annual population growth at $3 \%$ per annum (trend 0.08 (95\% CI 0.02-0.14, t-stats $2.79, \mathrm{p}=0.01)$. The median age of the neonates at admission decreased significantly from 7 days (IQR 11 , 3; 14 days) in 1990 to 3 days (IQR 10, 0; 10 days) by 2008 (trend -0.212 (95\% Confidence interval (CI) -0.267$0.156)$, t-stats $8.01, \mathrm{p}<0.001)$ ). Overall very young neonates (<7days old) comprised $5400(62 \%)$ of the total neonatal admissions. Neonates aged $<7$ days increased from just 119 cases in 1990 to 577 cases by 2008, an increment of $385 \%$, whilst the remainder of neonatal admissions registered an increment of only $40 \%$ over the same period.

The clinical diagnoses of neonatal sepsis, prematurity, neonatal jaundice, neonatal encephalopathy, tetanus and neonatal meningitis comprised over $75 \%$ of the inpatient neonatal admissions. Over the first 10 years (19901999), the number of admissions with neonatal sepsis, neonatal encephalopathy and neonatal jaundice increased significantly. However the proportion of total under five admissions that were neonatal remained unchanged (tstats 1.92, $\mathrm{p}=0.10$ ). In the second epoch (2000-2008), the number of neonates with diagnoses of neonatal jaundice and neonatal tetanus showed a slight decrease, while those with diagnoses of neonatal sepsis, prematurity and neonatal encephalopathy increased significantly (table 1). Although clinical diagnosis of neonatal sepsis increased the most from 1990 to 1999, increasing by $260 \%$, from 2000 , neonatal encephalopathy had the greatest increase (350\%). There was no significant change in the number of neonates with invasive bacterial disease (table 1).

The number of admissions among in-born neonates increased significantly from $40(9 \%)$ of all neonatal admissions in 2000 to 350 (47\%) in 2008 (trend 32.67 (95\% CI 25.29-40.05, t-stats 10.83, p < 0.001), an absolute increment of $775 \%$. In contrast, the burden of outborn ill neonates remained largely unchanged over the same period. The proportions of neonatal encephalopathy among inborn $(506 / 1,787(28 \%))$ was significantly higher than that among out-born $\left(186 / 3732(5 \%), \chi^{2}=\right.$ $600, \mathrm{P}<0.001)$.

Over the 19-year period, annual deliveries at the district hospital increased from 1,329 in 1990 to 2,597 by 2008, an increment of 95\% (fig 1). The year-to-year increment was significant (trend 72.5, t-stats 5.6, p < 0.001 ). The projected population of women within the reproductive age group in the catchment area increased by $17 \%$ over the same period [19].

Overall, neonatal inpatient case fatality was significantly higher; $2,053 / 8,756$ (23.5\%) compared to 3,664/ $63,096(5.8 \%)$ in the non-neonatal paediatric admissions aged $\leq 5$ years $\left(\chi^{2}=2.5 \mathrm{e}+03, \mathrm{P}<0.001\right)$ over the 19-year period. Of the neonatal deaths, 54 (2.6\%) occurred among newborn who though admitted as neonates, died after 28 days of life. The case fatalities for the main neonatal diagnoses were; tetanus 256/390 (65.6\%), prematurity 554/1,280(43.3\%), neonatal encephalopathy 253 / $778(35.1 \%)$, meningitis $39 / 147$ (26.5\%), sepsis $547 / 3,252$ (16.8\%) and neonatal jaundice 116/811(14.3\%) respectively.

Neonatal inpatient case fatality decreased from $30.8 \%$ in 1990 to $16.5 \%$ in 2008 with that in the rest of the $\leq 5$ years decreasing from $8.0 \%$ to $3.5 \%$ respectively (fig 2 ). The declining trend in both were significant (tstats -5.3 , $\mathrm{p}<0.001$ ) and (tstats $-3.7, \mathrm{p}=0.002$ ) respectively. However whilst annual deaths in the non-neonatal pediatric admissions aged $\leq 5$ years decreased by $31 \%$, annual neonatal deaths increased by $67 \%$. Overall neonatal deaths as a proportion of all $\leq 5$ years inpatient death increased significantly from 33\% in 1990 to 55\% in 2008 (tstats 6.3, $\mathrm{p}<0.001)$.

From 1990 to1999 the clinical diagnosis of neonatal sepsis had the greatest increase as a cause of inpatient neonatal death (table 2). However death from neonatal encephalopathy also increased significantly over the same period. From 2000 to 2008, whilst inpatient death from the clinical diagnoses of neonatal sepsis, neonatal tetanus and meningitis declined, that from neonatal encephalopathy continued to increase significantly (table 2). The case fatality rate of the most important causes of death declined from 1990 to 2008 as follows: prematurity 50\% to $30.8 \%$, neonatal meningitis $42.9 \%$ to $11.8 \%$, neonatal sepsis $30.6 \%$ to $5.5 \%$ and neonatal jaundice $25.7 \%$ to $3.6 \%$. The case fatality of neonates with invasive bacterial disease also declined from $42.5 \%$ in 1998 to $23.9 \%$ in 2008. The trend of declining case fatality was significant for the clinical diagnoses of neonatal sepsis and neonatal jaundice; (tstats -9.9, $\mathrm{p}<0.001$ ) and (tstats $-5.5, \mathrm{p}<$ 0.001 ) respectively and among those with invasive bacterial disease, (tstats $-6.5, \mathrm{p}<0.001$ ). The case fatality from neonatal tetanus and neonatal encephalopathy did not change significantly over the 19 years. 
Table 1 Overall trend in burden of individual clinical diagnoses 1990-2008

\begin{tabular}{|c|c|c|c|c|c|c|c|}
\hline \multicolumn{8}{|c|}{ Admissions annual cases } \\
\hline Year & $\begin{array}{l}\text { Neonatal } \\
\text { sepsis }\end{array}$ & $\begin{array}{l}\text { Culture } \\
\text { positive }\end{array}$ & Prematurity & $\begin{array}{c}\text { Neonatal } \\
\text { encephalopathy }\end{array}$ & $\begin{array}{l}\text { Neonatal } \\
\text { jaundice }\end{array}$ & $\begin{array}{l}\text { Neonatal } \\
\text { tetanus }\end{array}$ & $\begin{array}{c}\text { Neonatal } \\
\text { meningitis }\end{array}$ \\
\hline 1990 & 49 & - & 50 & - & - & 20 & 7 \\
\hline 1991 & 78 & - & 32 & 4 & - & 41 & 9 \\
\hline 1992 & 69 & - & 40 & 5 & - & 26 & 6 \\
\hline 1993 & 81 & - & 73 & 5 & - & 28 & 7 \\
\hline 1994 & 100 & - & 59 & 9 & - & 13 & 4 \\
\hline 1995 & 148 & - & 58 & 13 & - & 22 & 4 \\
\hline 1996 & 149 & - & 39 & 11 & - & 32 & 4 \\
\hline 1997 & 172 & - & 47 & 6 & 9 & 10 & 2 \\
\hline 1998 & 134 & 54 & 41 & 11 & 35 & 26 & 1 \\
\hline 1999 & 178 & 70 & 57 & 22 & 38 & 25 & 3 \\
\hline $\begin{array}{l}\text { Trend:1990- } \\
\text { 1999(95\%Cl) }\end{array}$ & $\begin{array}{c}13.8 \\
(8.2-19.4)\end{array}$ & $* *$ & $\begin{array}{c}0.6 \\
(-4.1-5.3)\end{array}$ & $\begin{array}{c}1.6 \\
(0.3-2.9)\end{array}$ & $* *$ & $\begin{array}{c}-1.3 \\
(-3.0-0.5)\end{array}$ & $\begin{array}{c}-0.8 \\
(-1.0 \text { to }-0.7)\end{array}$ \\
\hline t-stats & 5.78 & - & 0.30 & 3.0 & - & -1.75 & -12.9 \\
\hline Pvalue & 0.001 & - & 0.77 & 0.02 & - & 0.12 & $<0.001$ \\
\hline 2000 & 144 & 55 & 61 & 29 & 46 & 25 & 9 \\
\hline 2001 & 149 & 52 & 72 & 37 & 91 & 27 & 5 \\
\hline 2002 & 227 & 51 & 79 & 37 & 65 & 23 & 12 \\
\hline 2003 & 234 & 51 & 79 & 68 & 88 & 6 & 14 \\
\hline 2004 & 245 & 57 & 64 & 57 & 91 & 11 & 11 \\
\hline 2005 & 274 & 75 & 90 & 100 & 118 & 12 & 17 \\
\hline 2006 & 238 & 58 & 106 & 120 & 91 & 12 & 6 \\
\hline 2007 & 276 & 57 & 97 & 111 & 84 & 18 & 9 \\
\hline 2008 & 307 & 46 & 136 & 133 & 55 & 13 & 17 \\
\hline $\begin{array}{l}\text { Trend:2000- } \\
\text { 2008(95\%Cl) }\end{array}$ & $\begin{array}{c}16.5 \\
(6.2-26.7)\end{array}$ & $\begin{array}{c}0.0 \\
(-4.5-4.5)\end{array}$ & $\begin{array}{c}7.3 \\
(2.8-11.8)\end{array}$ & $\begin{array}{c}14.6 \\
(11.3-17.8)\end{array}$ & $\begin{array}{c}-2.7 \\
(-11.7-6.2)\end{array}$ & $\begin{array}{c}-1.0 \\
(-4.5-2.6)\end{array}$ & $\begin{array}{c}0.5 \\
(-0.8-1.9)\end{array}$ \\
\hline t-stats & 3.94 & 0.0 & 4.00 & 10.86 & -0.74 & -1.66 & 0.93 \\
\hline Pvalue & 0.008 & 1.0 & 0.007 & $<0.001$ & 0.49 & 0.54 & 0.39 \\
\hline $\begin{array}{l}\text { Overall Trend: } \\
\text { 1990-2008 (95\%Cl) }\end{array}$ & $\begin{array}{c}13.1 \\
(10.7-15.6)\end{array}$ & $\begin{array}{c}-0.6 \\
(-3.1-1.9)\end{array}$ & $\begin{array}{c}4.8 \\
(2.4-7.2)\end{array}$ & $\begin{array}{c}11.0 \\
(5.7-16.3)\end{array}$ & $\begin{array}{c}5.9 \\
(1.7-10.2)\end{array}$ & $\begin{array}{c}-1.0 \\
(-1.6 \text { to }-0.4)\end{array}$ & $\begin{array}{c}0.6 \\
(0.06-1.2)\end{array}$ \\
\hline t-stats & 11.3 & -0.58 & 4.2 & 4.4 & 2.9 & -3.6 & 2.35 \\
\hline P-Value & $<0.001$ & 0.58 & 0.001 & $<0.001$ & 0.01 & 0.002 & 0.03 \\
\hline
\end{tabular}

** Trend analysis not done where data available for $<5 y e a r s$

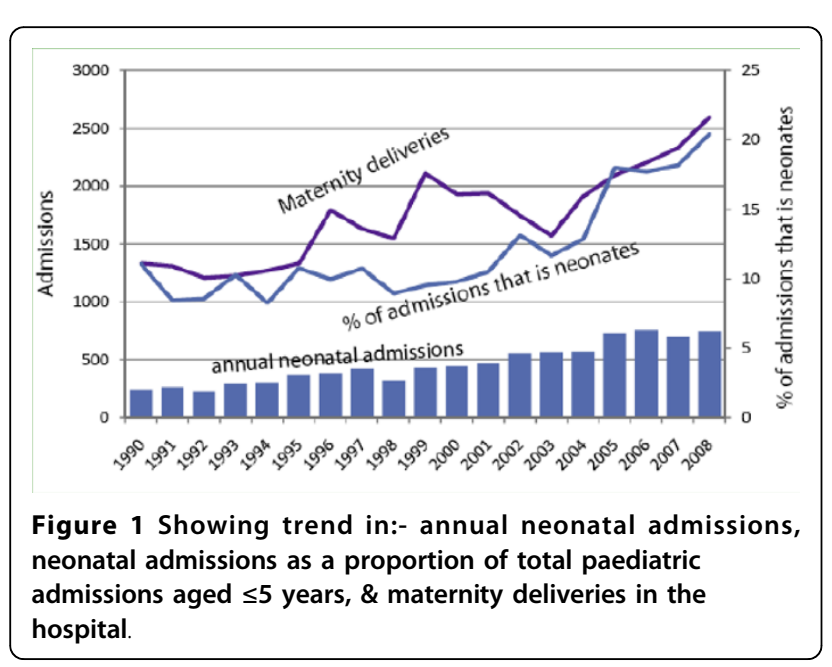

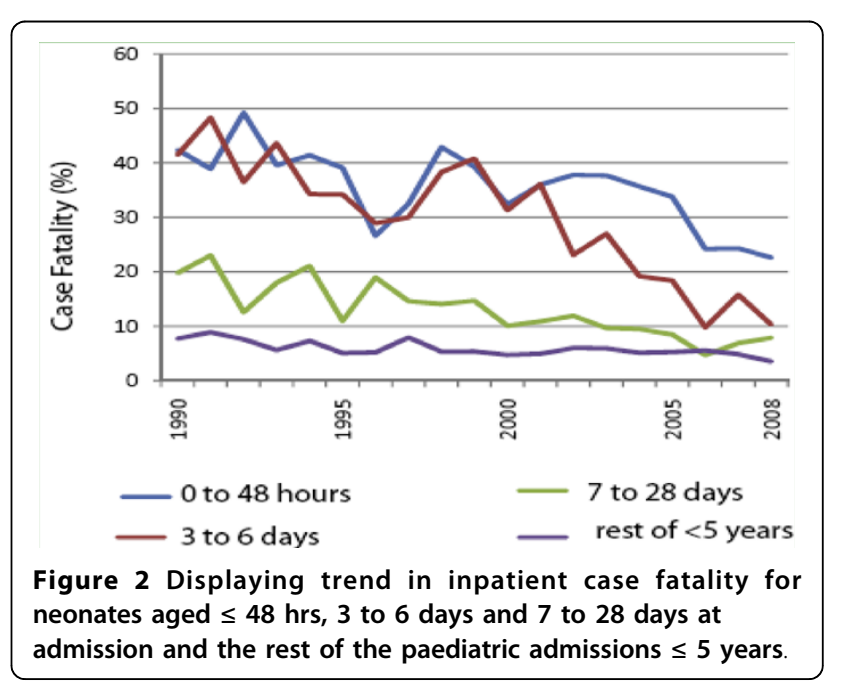


Table 2 Overall trend in inpatient death: 1990-2008

\begin{tabular}{|c|c|c|c|c|c|c|c|c|c|c|}
\hline \multicolumn{11}{|c|}{ Death annual cases } \\
\hline Year & $\begin{array}{c}\text { All } \\
\text { neonates }\end{array}$ & $\begin{array}{r}\text { Other } \\
\leq \text { 5years } \\
\text { admissions }\end{array}$ & $\begin{array}{r}\text { Neonatal } \\
\text { sepsis }\end{array}$ & prematurity & $\begin{array}{c}\text { Neonatal } \\
\text { encephalopathy }\end{array}$ & $\begin{array}{l}\text { Neonatal } \\
\text { jaundice }\end{array}$ & $\begin{array}{l}\text { Neonatal } \\
\text { tetanus }\end{array}$ & $\begin{array}{c}\text { Neonatal } \\
\text { meningitis }\end{array}$ & $\begin{array}{c}\text { Neonates } \\
\text { aged } \\
<7 \text { days }\end{array}$ & $\begin{array}{c}\text { Neonates } \\
\text { aged } 7-28 \\
\text { days }\end{array}$ \\
\hline 1990 & 74 & 149 & 15 & 25 & - & - & 12 & 3 & 50 & 24 \\
\hline 1991 & 84 & 253 & 21 & 10 & 1 & - & 34 & 4 & 50 & 34 \\
\hline 1992 & 67 & 186 & 25 & 17 & 1 & - & 15 & 2 & 54 & 13 \\
\hline 1993 & 91 & 142 & 23 & 34 & 3 & - & 17 & 3 & 69 & 22 \\
\hline 1994 & 93 & 245 & 32 & 30 & 0 & - & 12 & 2 & 65 & 28 \\
\hline 1995 & 95 & 154 & 31 & 31 & 4 & - & 15 & 0 & 78 & 17 \\
\hline 1996 & 90 & 177 & 35 & 15 & 4 & - & 22 & 0 & 60 & 30 \\
\hline 1997 & 104 & 279 & 51 & 20 & 1 & - & 5 & 2 & 79 & 25 \\
\hline 1998 & 96 & 174 & 34 & 17 & 3 & 9 & 17 & 1 & 78 & 18 \\
\hline 1999 & 128 & 220 & 42 & 22 & 12 & 11 & 20 & 1 & 102 & 26 \\
\hline $\begin{array}{l}\text { Trend } \\
1990-99 \\
(95 \% \mathrm{Cl})\end{array}$ & $\begin{array}{c}4.10 \\
(2.73-5.48)\end{array}$ & $\begin{array}{r}1.41 \\
(-7.02-9.84)\end{array}$ & $\begin{array}{c}2.95 \\
(1.78-4.11)\end{array}$ & $\begin{array}{c}0.13 \\
(-3.05-3.31)\end{array}$ & $\begin{array}{c}0.66 \\
(0.08-1.24)\end{array}$ & $* *$ & $\begin{array}{c}-1.02 \\
(-2.36-0.33)\end{array}$ & $\begin{array}{c}-0.32 \\
(-0.64-0.01)\end{array}$ & $\begin{array}{c}4.46 \\
(2.91-6.00)\end{array}$ & $\begin{array}{c}-0.22 \\
(-1.47-1.02)\end{array}$ \\
\hline t-stats & 7.04 & 0.40 & 5.99 & 0.10 & 2.68 & - & -1.78 & -2.29 & 6.82 & 0.43 \\
\hline P-Value & 0.001 & 0.70 & 0.001 & 0.92 & 0.03 & - & 0.12 & 0.06 & $<0.001$ & 0.68 \\
\hline 2000 & 104 & 192 & 26 & 28 & 10 & 7 & 17 & 3 & 87 & 17 \\
\hline 2001 & 122 & 197 & 19 & 34 & 12 & 27 & 19 & 0 & 102 & 20 \\
\hline 2002 & 131 & 218 & 33 & 42 & 15 & 13 & 12 & 3 & 105 & 26 \\
\hline 2003 & 139 & 252 & 38 & 35 & 29 & 14 & 4 & 4 & 118 & 21 \\
\hline 2004 & 128 & 199 & 33 & 38 & 19 & 11 & 6 & 2 & 108 & 20 \\
\hline 2005 & 151 & 174 & 30 & 50 & 31 & 9 & 7 & 6 & 127 & 24 \\
\hline 2006 & 111 & 197 & 20 & 35 & 34 & 5 & 4 & 1 & 98 & 13 \\
\hline 2007 & 120 & 153 & 22 & 29 & 32 & 8 & 9 & 0 & 105 & 15 \\
\hline 2008 & 124 & 103 & 17 & 42 & 42 & 2 & 9 & 2 & 111 & 13 \\
\hline $\begin{array}{l}\text { Trend } \\
\text { 2000-08 } \\
(95 \% \mathrm{Cl})\end{array}$ & $\begin{array}{c}-1.30 \\
(-6.22-3.63)\end{array}$ & $\begin{array}{r}-21.56 \\
(-41.50-1.62)\end{array}$ & $\begin{array}{c}-2.37 \\
(-7.03-2.30)\end{array}$ & $\begin{array}{c}0.07 \\
(-2.32-2.46)\end{array}$ & $\begin{array}{c}3.74 \\
(2.93-4.54)\end{array}$ & $\begin{array}{c}-2.27 \\
(-2.69-1.85)\end{array}$ & $\begin{array}{c}-0.25 \\
(-3.43-2.94)\end{array}$ & $\begin{array}{c}-0.08 \\
(-0.88-0.62)\end{array}$ & $\begin{array}{c}4.22 \\
(1.91-6.53)\end{array}$ & $\begin{array}{c}-5.37 \\
(-9.40-1.35)\end{array}$ \\
\hline t-stats & -0.64 & -2.65 & -.1 .24 & 0.07 & 11.35 & -13.14 & -0.19 & -0.27 & 4.47 & -3.27 \\
\hline Pvalue & 0.54 & 0.04 & 0.26 & 0.94 & $<0.001$ & $<0.001$ & 0.86 & 0.80 & 0.004 & 0.02 \\
\hline $\begin{array}{l}\text { Trend } \\
1990-2008 \\
(95 \% \mathrm{Cl})\end{array}$ & $\begin{array}{c}3.31 \\
(2.03-4.60)\end{array}$ & $\begin{array}{r}-2.10 \\
(-5.55-1.35)\end{array}$ & $\begin{array}{c}-0.77 \\
(-2.230 .69)\end{array}$ & $\begin{array}{c}1.42 \\
(0.43-2.42)\end{array}$ & $\begin{array}{c}2.58 \\
(1.79-3.37)\end{array}$ & $\begin{array}{c}0.49 \\
(-0.55-1.53)\end{array}$ & $\begin{array}{c}-0.92 \\
(-1.37 \text { to } 0.46)\end{array}$ & $\begin{array}{c}0.01 \\
(-0.17-0.18)\end{array}$ & $\begin{array}{c}3.84 \\
(2.79-4.89)\end{array}$ & $\begin{array}{c}-0.51 \\
(-0.87 \text { to } 0.15)\end{array}$ \\
\hline t-stats & 5.46 & -1.29 & -.1 .12 & 3.04 & 6.93 & 1.0 & -4.24 & 0.06 & 7.76 & -2.97 \\
\hline PValue & 0.001 & 0.22 & $<0.001$ & 0.001 & $<0.001$ & 0.01 & 0.002 & 0.03 & $<0.001$ & 0.009 \\
\hline
\end{tabular}

** Trend analysis not done where data available for $<5$ years. 
Most death's occurred during the first week of life, with $70 \%$ of all deaths occurring within the first fortyeight hours of life. Overall death among the very young neonates (<7days old) was significantly higher; 1,647/ $5,400(30.5 \%)$ compared to the rest of the neonatal per$\operatorname{iod} 406 / 3,356(12.1 \%)\left(\chi^{2}=252, \mathrm{P}<0.001\right)$ over the 19year period. From the year 2000, neonates that died within forty-eight hours of life were more likely to be cases of neonatal encephalopathy $\left(\chi^{2}=11.1, \mathrm{P}=0.001\right)$. They were also more likely to be in-born rather than out-born $\left(\chi^{2}=4.5, \mathrm{P}=0.03\right)$. However the overall proportions of deaths among inborn cases of neonatal encephalopathy (154/506(30.4\%), did not significantly differ from that among out-born cases of neonatal encephalopathy $\left(70 / 186(37.6 \%), \chi^{2}=3.22, \mathrm{P}=0.07\right)$. Likewise the overall case fatality rates among in-born $(19.5 \%)$ and out-born $(20.9 \%)$ did not differ significantly $\left(\chi^{2}=0.34\right.$, $\mathrm{P}=0.56)$.

Variables that appeared predictive of inpatient neonatal death in univariable $(\mathrm{LR} \geq 2.0)$ analysis were abnormal axillary temperature $\left(<36^{\circ} \mathrm{C}\right.$ or $\left.\geq 39.5^{\circ} \mathrm{C}\right)$, irregular breathing, respiratory rate of $<30$ per minute, cyanosis, oxygen saturation of $<90 \%$, temperature gradient, a weak pulse, delayed capillary refill $\geq 3$ seconds, heart rate of $<100$ per minute, pallor, inability to breastfeed, no cry, neck stiffness, weight $<1.5 \mathrm{~kg}$ and blood glucose concentration $>7.0 \mathrm{mmols} / \mathrm{l}$ (table 3 ). Of the clinical diagnoses, only neonatal tetanus and prematurity appeared predictive. However only irregular respiration, oxygen saturation of $<90 \%$, pallor, neck stiffness, weight $<1.5 \mathrm{~kg}$, abnormally elevated blood glucose $>7 \mathrm{mmol} / \mathrm{l}$, and clinical diagnosis of neonatal tetanus were independent predictors of inpatient neonatal death in multivariable analysis (table 4). There was no significant variation in the prevalence of these signs during the study period. The overall area under the ROC curve was 0.76 (95\%CI $0.74-0.77$ ), and it did not differ during and after the first week of life $\left(\chi^{2}=3.3, P=0.07\right)$ (fig 3). Exclusion of the diagnosis of neonatal tetanus had minimal effect on the over all performance of the indicators; ROC $0.74(95 \% \mathrm{CI}$ $0.74-0.77$. the remaining six indicators predicted inpatient neonatal death with a sensitivity of $81 \%$ and a specificity of $68 \%$.

\section{Discussion}

District health facilities play a pivotal role in the health care delivery system in resource poor countries, acting both as primary referral centres and also coordinating care at the peripheral health facilities $[34,35]$. The nature and composition of inpatient burden at this level may reflect the community burden, more so than that at the larger referral hospitals (provincial, national, and teaching hospitals) that are usually situated in urban centres and thus far removed from the rural communities. However no study has analysed secular trends of neonatal admissions and outcome in rural district hospitals from resource poor countries in general and Sub-Saharan Africa in particular. Our data shows that neonatal admissions both in absolute numbers and as a proportion of total paediatric admissions have substantially increased over the last 19 years. The age and pattern of neonatal admissions appears to have also changed, with much younger neonates and an increase in the cases of neonatal encephalopathy.

We found that although the total annual paediatric admissions increased markedly over the first 10 years of our surveillance (1990 to 1999), the proportions of neonatal admissions remained unchanged. Over the following nine year period (2000 to 2008) while neonatal admissions continued to increase markedly, non-neonatal admissions remained stable and even declined. While the increase in neonatal sepsis (almost three fold) accounted for much of the increase during the first 10 years of this surveillance, from 2000 onward neonatal encephalopathy was the largest increment.

It is worth noting that while hospital deliveries nearly doubled, the projected population of women within the reproductive age group increased marginally over the 19 years [19]. This may thus signify increased utilisation. The results may further support a previous research finding that pregnant women, even in rural settings would prefer skilled attendance during delivery [36]. Increasing coverage of skilled deliveries should be one of the core strategies for reducing neonatal mortality in developing countries [3]. However given the finding of higher cases of neonatal encephalopathy among hospital deliveries, studies to examine barriers of timely uptake of such facilities and how they can be eliminated are needed.

Encouragingly, this study shows a significant drop in inpatient case fatalities in both neonatal and non neonatal admissions aged $\leq 5$ years. This trend seems to be mirrored at national level where under five mortality rates appear to have initially increased from $89 / 1000$ in 1990 , to $114 / 1000$ by the year 2003 , with steady reduction to $74 / 1000$ live births by the year 2008 [37,38]. It is plausible that the initial increase was occasioned by economic deterioration in the late 1980s' through to 2002 resulting in poor quality of life and reduction in government investment in health care. The periods from 2003 onward saw renewed economic growth and increased government spending in health care [38]. Importantly our finding that there was no significant variation in the prevalence of signs indicative of severe illness or high likelihood of inpatient death over the this period, denotes that the decline in case fatality may be due to improving care rather than admission of less severely ill children. However, although inpatient neonatal and non 
Table 3 Crude predictors of inpatient neonatal death in univariable analysis

\begin{tabular}{|c|c|c|c|c|}
\hline Signs & Alive & Died & $\begin{array}{r}\text { Crude LR } \\
\text { (univariable) }\end{array}$ & $95 \% \mathrm{Cl}$ \\
\hline Fever & 1,793 & 250 & 0.54 & $0.48-0.61$ \\
\hline No Fever & 2,595 & 881 & 1.32 & $1.27-1.37$ \\
\hline Axilary temperature $<36^{\circ} \mathrm{C}$ & 816 & 533 & 2.62 & $2.40-2.86$ \\
\hline $36^{\circ} \mathrm{C}$ to $37.4^{\circ} \mathrm{C}$ & 2,369 & 314 & 0.53 & $0.48-0.59$ \\
\hline $37.5^{\circ} \mathrm{C}$ to $38.4^{\circ} \mathrm{C}$ & 830 & 128 & 0.62 & $0.52-0.74$ \\
\hline $38.5^{\circ} \mathrm{C}$ to $39.4^{\circ} \mathrm{C}$ & 290 & 71 & 0.98 & $0.77-1.26$ \\
\hline$\geq 39.5^{\circ} \mathrm{C}$ & 58 & 40 & 2.77 & $1.86-4.12$ \\
\hline Cough & 749 & 66 & 1.14 & $1.11-1.16$ \\
\hline No Cough & 3,639 & 1,065 & 0.34 & $0.27-0.44$ \\
\hline Indrawing & 1,337 & 519 & 1.51 & $1.39-1.63$ \\
\hline No indrawing & 3,051 & 612 & 0.78 & $0.74-0.82$ \\
\hline Wheeze & 30 & 8 & 1.04 & $0.48-2.26$ \\
\hline No wheeze & 4,088 & 1,049 & 1.00 & $0.99-1.01$ \\
\hline Stridor & 21 & 6 & 1.10 & $0.44-2.72$ \\
\hline No stridor & 4,308 & 1,120 & 1.00 & $1.00-1.004$ \\
\hline Irregular breathing & 280 & 252 & 3.60 & $3.08-4.20$ \\
\hline Regular breathing & 3,545 & 705 & 0.80 & $0.77-0.83$ \\
\hline No Deep breathing & 3,516 & 858 & 0.903 & $0.88-0.93$ \\
\hline Difficulty in breathing & 1,240 & 443 & 1.37 & $1.27-1.49$ \\
\hline No difficulty in breathing & 2,098 & 426 & 0.78 & $0.73-0.84$ \\
\hline Nasal flaring & 589 & 238 & 1.43 & $1.25-1.63$ \\
\hline No nasal flaring & 2,661 & 682 & 0.91 & $0.87-0.94$ \\
\hline BCG scar & 885 & 103 & 0.43 & $0.36-0.52$ \\
\hline No BCG scar & 2,814 & 898 & 1.18 & $1.15-1.21$ \\
\hline $\begin{array}{l}\text { Respiratory rate (per minute) } \\
<30\end{array}$ & 212 & 181 & 3.33 & $2.76-4.01$ \\
\hline 30 to 59 & 2,894 & 591 & 0.80 & $0.75-0.84$ \\
\hline 60 to 80 & 969 & 264 & 1.06 & $0.94-1.20$ \\
\hline$>80$ & 236 & 70 & 1.16 & $0.89-1.50$ \\
\hline Cyanosis & 205 & 208 & 3.90 & $3.25-4.68$ \\
\hline No Cyanosis & 4,123 & 918 & 0.86 & $0.83-0.88$ \\
\hline $\begin{array}{l}\text { Oxygen saturation (\%) } \\
<90\end{array}$ & 605 & 457 & 2.94 & $2.66-3.26$ \\
\hline 90 to 100 & 3,072 & 666 & 0.69 & $0.66-0.72$ \\
\hline Diarrhoea & 66 & 11 & 0.65 & $0.34-1.22$ \\
\hline No diarrhoea & 4,322 & 1,120 & 1.01 & $1.00-1.01$ \\
\hline Vomiting & 230 & 26 & 0.44 & $0.29-0.65$ \\
\hline No Vomiting & 4,158 & 1,105 & 1.03 & $1.02-1.043$ \\
\hline Decreased skin turgor & 135 & 46 & 1.21 & $0.87-1.68$ \\
\hline Normal skin turgor & 3,012 & 839 & 0.99 & $0.97-1.01$ \\
\hline Sunken eyes & 59 & 17 & 1.13 & $0.66-1.93$ \\
\hline No sunken eyes & 3,851 & 978 & 1.00 & $0.99-1.08$ \\
\hline Temperature gradient & 443 & 297 & 2.48 & $2.18-2.82$ \\
\hline No temperature gradient & 3,087 & 657 & 0.79 & $0.75-0.82$ \\
\hline Weak pulse & 197 & 226 & 4.43 & $3.72-5.28$ \\
\hline Normal pulse & 3,004 & 606 & 0.78 & $0.74-0.81$ \\
\hline $\begin{array}{l}\text { Capillary refill time(seconds) } \\
<1\end{array}$ & 2,578 & 449 & 0.67 & $0.62-0.72$ \\
\hline 1 to 3 & 1,670 & 566 & 1.31 & $1.22-1.40$ \\
\hline$>3$ & 80 & 109 & 5.25 & $3.96-6.95$ \\
\hline $\begin{array}{l}\text { Heart rate(per minute) } \\
<100\end{array}$ & 130 & 124 & 3.566 & $2.82-4.52$ \\
\hline
\end{tabular}


Table 3: Crude predictors of inpatient neonatal death in univariable analysis (Continued)

\begin{tabular}{|c|c|c|c|c|}
\hline 100 to 180 & 3,077 & 725 & 0.881 & $0.85-0.92$ \\
\hline$>180$ & 558 & 158 & 1.059 & $0.90-1.5$ \\
\hline Pallor & 225 & 170 & 2.93 & $2.43-3.54$ \\
\hline No Pallor & 4,163 & 961 & 0.90 & $0.87-0.92$ \\
\hline breastfeeding & 2,883 & 369 & 0.49 & $0.45-0.54$ \\
\hline Not able to breastfeed & 1,442 & 758 & 2.02 & $1.90-2.14$ \\
\hline cry & 3,184 & 614 & 0.77 & $0.73-0.81$ \\
\hline No cry & 642 & 344 & 2.14 & $1.92-2.39$ \\
\hline Bulging fontanel & 45 & 19 & 1.77 & $0.99-2.87$ \\
\hline Normal fontanel & 3,767 & 935 & 0.99 & $0.98-1.00$ \\
\hline Neck stiffness & 29 & 26 & 3.48 & $2.06-5.88$ \\
\hline No neck stiffness & 4,286 & 1,087 & 0.98 & $0.97-0.99$ \\
\hline irritable & 109 & 55 & 1.97 & 1.432 .70 \\
\hline Not irritable & 4,007 & 1,001 & 0.97 & $0.96-0.99$ \\
\hline Convulsions & 247 & 45 & 0.68 & $0.50-0.93$ \\
\hline No convulsions & 3,513 & 964 & 1.02 & $1.01-1.04$ \\
\hline $\begin{array}{l}\text { Weight(kg) } \\
<1.5\end{array}$ & 367 & 381 & 4.18 & $3.68-4.74$ \\
\hline 1.5 to $<2.0$ & 492 & 150 & 1.23 & $1.03-1.45$ \\
\hline 2.0 to $<2.5$ & 769 & 166 & 0.87 & $0.74-1.01$ \\
\hline$\geq 2.5$ & 2,727 & 386 & 0.57 & $0.52-0.62$ \\
\hline $\begin{array}{l}\text { Age in days } \\
0 \text { to } 2\end{array}$ & 1,335 & 619 & 1.73 & $1.62-1.85$ \\
\hline 3 to 6 & 808 & 231 & 1.07 & $0.94-1.22$ \\
\hline 7 to 28 & 1,615 & 156 & 0.36 & $0.31-0.42$ \\
\hline Neonatal encephalopathy & 298 & 150 & 1.81 & $1.51-2.17$ \\
\hline Not neonatal encephalopathy & 2,888 & 737 & 0.92 & 0.89-0.95 \\
\hline Neonatal tetanus & 47 & 69 & 5.27 & $3.67-7.58$ \\
\hline Not neonatal tetanus & 3,139 & 818 & 0.94 & $0.92-0.96$ \\
\hline preterm & 289 & 262 & 3.26 & $2.80-3.78$ \\
\hline Not preterm & 2,897 & 625 & 0.78 & $0.74-0.81$ \\
\hline Neonatal sepsis & 1,332 & 199 & 0.54 & $0.47-0.61$ \\
\hline Not neonatal sepsis & 1,854 & 688 & 1.33 & $1.27-1.40$ \\
\hline meningitis & 55 & 19 & 1.24 & $0.74-2.08$ \\
\hline Not meningitis & 3,131 & 868 & 1.00 & $0.99-1.01$ \\
\hline Jaundice & 509 & 86 & 0.61 & $0.49-0.75$ \\
\hline Not jaundice & 2,667 & 809 & 1.08 & $1.05-1.10$ \\
\hline $\begin{array}{l}\text { Blood glucose level(mmols/l) } \\
<2.6\end{array}$ & 705 & 279 & 1.44 & $1.28-1.62$ \\
\hline$\geq 2.6$ to $\leq 7.0$ & 2,327 & 422 & 0.66 & $0.61-0.71$ \\
\hline$>7.0$ & 236 & 199 & 3.06 & $2.57-3.64$ \\
\hline Culture (blood or CSF) Positive & 370 & 171 & 1.81 & 1.527 to 2.133 \\
\hline Negative & 3,437 & 804 & 0.91 & 0.886 to 0.942 \\
\hline
\end{tabular}

neonatal case fatality rates decreased over the 19 years, the actual numbers of neonatal inpatient deaths markedly increased as a result of the higher admissions. Importantly, neonatal deaths as a proportion of all inpatient deaths in children aged $\leq 5$ years nearly doubled. It is particularly noteworthy that neonatal encephalopathy was the most rapidly increasing cause of inpatient neonatal deaths over the entire 19-year period.
Importantly while the case fatality from neonates with IBD or a clinical diagnosis of neonatal sepsis declined significantly, that from neonatal encephalopathy remained high. In the sub-Saharan African region, though neonatal encephalopathy and birth related complications are thought to be responsible for nearly a quarter of all neonatal deaths, the bulk of neonatal deaths is thought to be due to infectious causes (sepsis) 
Table 4 Predictors of inpatient neonatal death (Multivariable analysis of crude predictors with LR $\geq 2.0$ )

\begin{tabular}{|c|c|c|c|c|c|}
\hline Signs & Alive & Died & $\begin{array}{r}\text { Crude LR } \\
\text { (univariable) }\end{array}$ & $95 \% \mathrm{Cl}$ & $\begin{array}{r}\text { Adjusted LR } \\
\text { (multivariable) }\end{array}$ \\
\hline Irregular breathing & 280 & 252 & 3.60 & $3.08-4.20$ & 1.93 \\
\hline $\begin{array}{l}\text { Oxygen saturation (\%) } \\
<90\end{array}$ & 605 & 457 & 2.94 & $2.66-3.26$ & 2.00 \\
\hline Pallor & 225 & 170 & 2.93 & $2.43-3.54$ & 2.49 \\
\hline Neck stiffness & 29 & 26 & 3.48 & $2.06-5.88$ & 3.42 \\
\hline $\begin{array}{l}\text { Weight(kg) } \\
<1.5\end{array}$ & 367 & 381 & 4.18 & $3.68-4.74$ & 4.03 \\
\hline $\begin{array}{l}\text { Blood glucose } \\
\text { level }(\mathrm{mmols} / \mathrm{l})>7.0\end{array}$ & 236 & 199 & 3.06 & $2.57-3.64$ & 2.14 \\
\hline Neonatal tetanus & 47 & 69 & 5.27 & $3.67-7.58$ & 7.38 \\
\hline
\end{tabular}

$[1,3,39]$. This increasing prominence of neonatal encephalopathy over time with declining deaths from other major neonatal conditions especially sepsis has not been previously reported. Surprisingly death among neonates with neonatal encephalopathy (whether in-born or outborn) did not differ significantly. However the higher composition of neonatal encephalopathy among inborns suggests that hospital deliveries may be occurring either for complicated births or where attempted home delivery has failed. It is therefore possible that cases of neonatal encephalopathy from home may represent just a minority of the mild and moderately affected newborn, with the severe ones dying soon after birth before reaching hospital care. Of note too is the high case fatality from neonatal tetanus and prematurity. Lack of ventilatory support and parenteral nutrition at our centre may partly account for this. However this finding may underscore the role of primary prevention if significant gains in achieving sustained reduction in neonatal morbidity and mortality are to be made especially where the three conditions (neonatal encephalopathy, neonatal tetanus \& prematurity) are concerned.

There are several possible factors that could account for the increase in neonatal admissions and hospital deliveries with stabilization or even decline in non-neonatal admissions. Firstly is the sustained high fertility rate (estimated to be above 6.0) in the catchment area [40]. Secondly, a major cause of non-neonatal admissions notably malaria, has declined [11]. This could be due to a combination of factors such as increased coverage of insecticide treated mosquito nets and change to a more effective anti-malarial drug [13]. Moreover from 2001 introduction of Haemophilus influenzae type b conjugate vaccine led to a noticeable drop in cases admitted with IBD [9].

Trends in health facility utilization over the last two decades in Kenya need to be put into context considering that from late $1980 \mathrm{~s}$, the country introduced user

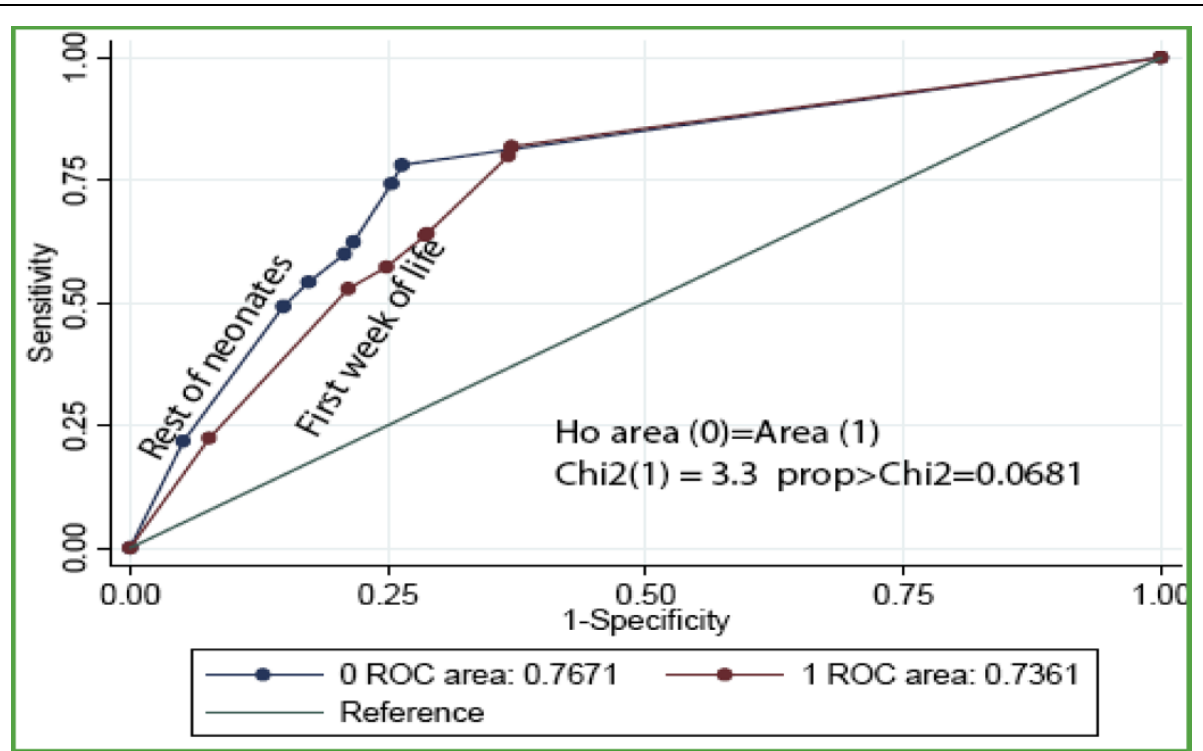

Figure 3 Performance of indicators of inpatient neonatal death. 
fees in public health facilities $[41,42]$. This was due to a combination of factors including poor economic performance, inadequate financial resources, declining budget allocations and international donor pressure [41]. Facilities set user fees locally with the support of health facility committees. Revenue collected was returned to the district level and facilities developed detailed plans for spending $75 \%$ of the revenue. A waiving policy to protect the poor was put in place, and children below five years were exempted from most charges, but in reality waiving and exemption mechanisms hardly existed [41]. Although there have been attempts towards lowering the user fees at lower level facilities (community dispensaries and health centres), this has not been effected at district hospital level. Evidence on user fees and other out of pocket payments in Kenya suggest that health care charges are a significant barrier to access [42,43], and that they can push households into poverty [43]. Indirect costs such as transport and potential loss of income are also important determinants of care seeking. It is therefore highly plausible that the trend we describe here has been greatly attenuated by combination of user fees, other out-of pocket payments and non financial barriers to accessing healthcare.

In order to reduce paediatric mortality in regions with limited resources, there have been attempts to develop diagnostic and treatment algorithms that target the principal causes of death in children $[16,44,45]$. The WHO developed a thirteen indicators sick child chart aimed at identifying severely ill children in need of intensive treatment or urgent referral [16]. This largely identified children with acute respiratory infections, malaria, measles, diarrhoeal diseases and malnutrition. Although neonatal deaths constitute close to $40 \%$ of all inpatient paediatric deaths in such regions, neonatal illness did not feature prominently in the development of the said chart. Our study demonstrates that simple clinical variables of irregular breathing, oxygen saturation $<90 \%$, pallor, weight $<1.5 \mathrm{~kg}$, blood glucose $>7.0 \mathrm{mmol} / \mathrm{l}$ and neck stiffness can predict inpatient neonatal death with good sensitivity and reasonable specificity. These variables may potentially aid in neonatal triage and thus help to reduce inpatient neonatal death. A recent multicentre study looking at clinical signs that predict severe illness in neonates and young infants $\leq 2$ months old found that the signs of history of difficulty in feeding, history of convulsion, movement only when stimulated, respiratory rate of sixty breaths or more per minute, severe chest wall in drawing and abnormal temperature $\left(\geq 37.5^{\circ} \mathrm{C}\right.$ or $\left.<35.5^{\circ} \mathrm{C}\right)$ predicted severe illness with a sensitivity of $85 \%$ and specificity of $75 \%$ [44]. However we did not find these variables to be independent predictors of inpatient neonatal death. This may suggest that signs that predict severe illness may differ from those that predict inpatient neonatal death. More studies are needed to validate the signs that we found to be predictive.

A major limitation of this study is that before 2000, information on place of delivery was not routinely collected making it difficult to compare long term trends between home deliveries and the hospital births. However given that at the start of 2000 only $40 / 442$ (9\%) of all neonatal admission were in-born, and the proportion increased thereafter, it is likely that in the preceding years hospital births were unlikely to be much higher than the 2000 figure. We were also unable to estimate the minimum incidence of neonatal admissions due to lack of information on live births in the catchment area. However we controlled for this by looking at trend in neonatal admissions as a proportion of total under five paediatrics admissions, and further adjusting for annual population growth rate.

\section{Conclusion}

In conclusion, this study provides clear evidence of increase in inpatient neonatal burden in a district hospital coupled, with an increase in maternity deliveries in a resource poor region. Encouragingly, inpatient case fatality reduced significantly. However neonatal deaths now comprise close to $60 \%$ of all inpatient deaths in children aged $\leq 5$ years and neonatal encephalopathy is a rapidly increasing cause of inpatient death. Our findings have several implications at facility, national and global levels. At the facility level measures should be put in place to ensure adequate equipment and trained personnel to handle emergency obstetric care, recognize and manage common neonatal conditions and perform simple resuscitation measures especially in cases of neonatal encephalopathy. Likewise audit of neonatal admissions and outcome should be encouraged at all health care facilities. At the national and international level sustained political will is required to formulate and implement deliberate policies aimed at reducing newborn morbidity and mortality and to mobilize and direct resources towards implementing and sustaining such policies. The place of district and community level health facilities in reducing neonatal morbidity and mortality in developing regions should also be emphasised and committed steps taken to ensure they are appropriately staffed and equipped. Finally, by further highlighting simple variables predictive of inpatient neonatal death, this study also provides possible areas to be targeted in tackling the high level of inpatient neonatal deaths in rural district hospitals.

Declaration of commercial interest

None. 


\section{Competing interests}

The authors declare that they have no competing interests.

\section{Guarantor/sponsor}

Wellcome trust.

\section{Role of sponsor}

The sponsor played no role in study design, data collection, and analysis and manuscript preparation

\section{Authors' contributions}

MKM designed the study, collected and analyzed the data and wrote the draft. HG participated in data analysis. ME, JB, NM \& CC supervised inpatient care and assisted in collection and data analysis. JC reviewed the manuscript and provided contextual insights on affordability and payment for health in Kenya. NP, LM, PK \& KM participated in overall study conception and draft writing. CN suggested the study, participated in study design, and was involved in data analysis and preparation of the final manuscript for submission. All authors critically reviewed the final manuscript.

\section{Acknowledgements}

The authors are indebted to the medical, nursing, records and other staff at Kilifi District Hospital for their dedication and hard work. We would like to thank the Hospital Superintendent Dr. Iqbal Khandwalla and the District Medical Officers of Health Dr. Benjamin Tsofa. Kevin Marsh, Mike English, Charles Newton and Jay Berkley are funded by the Wellcome Trust. The work was supported by the Wellcome Trust, grant code (077092/B/05/Z) and KEMRI. The funding bodies played no part in design and conduct of the study; collection, management, analysis and interpretation of data and manuscript preparation. The corresponding author (MKM) had full access to all the data in the study and takes full responsibility for the integrity of the data, and accuracy of the data analysis. This manuscript is submitted for publication with the permission of the Director of KEMRI.

\section{Author details}

${ }^{1}$ Centre for Geographic Medicine Research (Coast), Kenya Medical Research Institute, PO Box 230, Kilifi, Kenya. ${ }^{2}$ Liverpool University, Liverpool, UK. ${ }^{3}$ Department of Infectious Diseases, Tropical Medicine and AIDS, Academic Medical Centre, University of Amsterdam, Amsterdam, the Netherlands. ${ }^{4}$ Nuffield Department of Clinical Medicine, University of Oxford, John Radcliffe Hospital, Oxford, UK. ${ }^{5}$ Centre for clinical Vaccinology and Tropical medicine, Churchill Hospital, Oxford University, Oxford, UK. ${ }^{6}$ Clinical Research Unit, London School of Hygiene and Tropical Medicine, London, UK. ${ }^{7}$ Neurosciences Unit, Institute of Child Health, The Wolfson Centre, Mecklenburgh Square, London, WC1N 2AP, UK.

Received: 19 April 2010 Accepted: 6 October 2010 Published: 6 October 2010

\section{References}

1. Lawn JE, Cousens S, Zupan J: 4 million neonatal deaths: when? Where? Why? Lancet 2005, 365(9462):891-900.

2. Lawn JE, Manandhar A, Haws RA, Darmstadt GL: Reducing one million child deaths from birth asphyxia-a survey of health systems gaps and priorities. Health Res Policy Syst 2007, 5:4.

3. In The Partnership for Maternal, Newborn \& Child Health, Opportunities for Africa's newborns:Practical data, policy and programmatic support for newborn care in Africa. Edited by: Joy Lawn, Kerber K. WHO; 2006:

4. Gordon AL, English M, Tumaini Dzombo J, Karisa M, Newton CR: Neurological and developmental outcome of neonatal jaundice and sepsis in rural Kenya. Trop Med Int Health 2005, 10(11):1114-20.

5. Gonzalez FF, Miller SP: Does perinatal asphyxia impair cognitive function without cerebral palsy? Arch Dis Child Fetal Neonatal Ed 2006, 91(6):F454-9.

6. Himmelmann K, Beckung E, Hagberg G, Uvebrant P: Bilateral spastic cerebral palsy-prevalence through four decades, motor function and growth. Eur J Paediatr Neurol 2007, 11(4):215-22.

7. Marlow N, Rose AS, Rands CE, Draper ES: Neuropsychological and educational problems at school age associated with neonatal encephalopathy. Arch Dis Child Fetal Neonatal Ed 2005, 90(5):F380-7.

8. Bhattarai A, Ali AS, Kachur SP, Martensson A, Abbas AK, Khatib R, AlMafazy AW, Ramsan M, Rotllant G, Gerstenmaier JF, Molteni F, Abdulla S,
Montgomery SM, Kaneko A, Bjorkman A: Impact of artemisinin-based combination therapy and insecticide-treated nets on malaria burden in Zanzibar. PLoS Med 2007, 4(11):e309.

9. Cowgill KD, Ndiritu M, Nyiro J, Slack MP, Chiphatsi S, Ismail A, Kamau T, Mwangi I, English M, Newton CR, Feikin DR, Scott JA: Effectiveness of Haemophilus influenzae type $b$ Conjugate vaccine introduction into routine childhood immunization in Kenya. JAMA 2006, 296(6):671-8.

10. Albrich WC, Baughman W, Schmotzer B, Farley MM: Changing characteristics of invasive pneumococcal disease in Metropolitan Atlanta, Georgia, after introduction of a 7-valent pneumococcal conjugate vaccine. Clin Infect Dis 2007, 44(12):1569-76.

11. Okiro EA, Hay SI, Gikandi PW, Sharif SK, Noor AM, Peshu N, Marsh K, Snow RW: The decline in paediatric malaria admissions on the coast of Kenya. Malar J 2007, 6:151.

12. Whitney CG, Farley MM, Hadler J, Harrison LH, Bennett NM, Lynfield R, Reingold A, Cieslak PR, Pilishvili T, Jackson D, Facklam RR, Jorgensen JH, Schuchat $A$ : Decline in invasive pneumococcal disease after the introduction of protein-polysaccharide conjugate vaccine. $N$ Engl J Med 2003, 348(18):1737-46.

13. Nyarango PM, Gebremeskel T, Mebrahtu G, Mufunda J, Abdulmumini U, Ogbamariam A, Kosia A, Gebremichael A, Gunawardena D, Ghebrat Y, Okbaldet $Y$ : A steep decline of malaria morbidity and mortality trends in Eritrea between 2000 and 2004: the effect of combination of control methods. Malar J 2006, 5:33.

14. WHO: The world health report-make every mother and child count [Online] [Cited 06/08/2010]. 2005 [http://www.who.int/whr/2005/ whr2005_en.pdf].

15. Ellis M, Allen S: Towards millennium development goal four. Arch Dis Child 2006, 91(9):728-30.

16. Paxton LA, Redd SC, Steketee RW, Otieno JO, Nahlen B: An evaluation of clinical indicators for severe paediatric illness. Bull World Health Organ 1996, 74(6):613-8.

17. Weber MW, Mulholland EK, Jaffar S, Troedsson H, Gove S, Greenwood BM: Evaluation of an algorithm for the integrated management of childhood illness in an area with seasonal malaria in the Gambia. Bull World Health Organ 1997, 75(Suppl 1):25-32.

18. WHO: IMCl chart booklet (Online) [Cited 06/08/2010] 2008 [http://whqlibdoc. who.int/publications/2008/9789241597289_eng.pdf].

19. Ministry of Planning, Kenya. Population and Housing Census 1999.

20. Berkley J, Mwangi I, Griffiths K, Ahmed I, Mithwani S, English M, Newton C, Maitland K: Assessment of severe malnutrition among hospitalized children in rural Kenya: comparison of weight for height and mid upper arm circumference. Jama 2005, 294(5):591-7.

21. English M, Berkley J, Mwangi I, Mohammed S, Ahmed M, Osier F, Muturi N, Ogutu B, Marsh K, Newton CR: Hypothetical performance of syndromebased management of acute paediatric admissions of children aged more than 60 days in a Kenyan district hospital. Bull World Health Organ 2003, 81(3):166-73.

22. Idro R, Ndiritu M, Ogutu B, Mithwani S, Maitland K, Berkley J, Crawley J, Fegan G, Bauni E, Peshu N, Marsh K, Neville B, Newton C: Burden, features, and outcome of neurological involvement in acute falciparum malaria in Kenyan children. Jama 2007, 297(20):2232-40.

23. WHO: Health Status Statistics Mortality (Online) [Cited 06/08/2010] 2009 [http://www.who.int/healthinfo/statistics/indneonatalmortality/en/]

24. Hospital care for children: Guidelines for the management of common illness with limited resources.(Online) [Cited 06/08/2010]. 2005 [http:// www.helid.desastres.net/gsdl2/tmp/export/who/s13431e.pdf].

25. International Child Health Care: A Practical Manual for Hospitals Worldwide. Child Advocacy International.Edited by: David Southall, Brian Coulter, Christiane Ronald, Sue Nicholson, Simon Parke. BMJ Books; , 1 2002:362-372.

26. Eregie CO: Assessment of gestational age: modification of a simplified method. Dev Med Child Neurol 1991, 33(7):596-600.

27. Testing the assumptions of linear regression (Online) [Cited 26/06/2009]. [http://www.duke.edu/ rnau/testing.htm].

28. Time series analysis (Online) [Cited 26/06/2009]. [http://www.statsoft. com/textbook/sttimser.html].

29. Statacorp press, CS., Texas USA: Stata time-series reference manual release 9 2005.

30. Centre for evidence based medicine: Likelihood Ratios (Online) [Cited 06/ 08/2010].[http://www.cebm.net/index.aspx?o = 1162]. 
31. Speigelhalter DJ, RP K-J: Statistical and knowledge-based approaches to clinical decision-support systems, with an application in gastroenterology. J R Stat Soc 1984, 147:35-77.

32. Berkley JA, Versteeg AC, Mwangi I, Lowe BS, Newton CR: Indicators of acute bacterial meningitis in children at a rural Kenyan district hospital. Pediatrics 2004, 114(6):e713-9.

33. Mwaniki MK, Nokes D, Ignas J, Munywoki P, Ngama M, Newton CR, Maitland K, Berkley JA: Emergency triage assessment for hypoxaemia in neonates and young children in a Kenyan hospital: an observational study. Bull World Health Organ 2009, 87(4):263-70.

34. Snow RW, Mung'ala VO, Foster D, Marsh K: The role of the district hospital in child survival at the Kenyan Coast. Afr J Health Sci 1994, 1(2):71-75.

35. Pearson CA: The role of district hospitals and the action in international medicine network. Infect Dis Clin North Am 1995, 9(2):391-405.

36. van den Boogaard J, Arntzen B, Chilwana J, Liyungu M, Mantingh A, Stekelenburg J: Skilled or traditional birth attendant? Choices of communities in Lukulu District, rural Zambia. World Health Popul 2008, 10(1):34-43.

37. Central Bureau of Statistics (CBS) [Kenya], Ministry of Health (MOH) [Kenya] and ORC Macro 2004. Kenya Demographic and Health Survey Key Findings Calverton, Maryland, USA: CBS, MOH and ORC Macro 2003.

38. Central Bureau of Statistics (CBS): [Kenya], Ministry of Health (MOH) [Kenya]. Kenya demographic and health survey 2008-2009 preliminary report 2009.

39. English M, Muhoro A, Aluda M, Were S, Ross A, Peshu N: Outcome of delivery and cause-specific mortality and severe morbidity in early infancy: a Kenyan District Hospital birth cohort. Am J Trop Med Hyg 2003, 69(2):228-32.

40. Ministry of Health (MO.H) [Kenya], Kilifi district health annual report. 2006.

41. Mwabu GM, Mwangi WM: Health care financing in Kenya: a simulation of welfare effects of user fees. Soc Sci Med 1986, 22(7):763-7.

42. Collins D, Quick JD, Musau SN, Kraushaar K, Hussein IM: The fall and rise of cost sharing in Kenya: the impact of phased implementation. Health Policy Plan 1996, 11(1):52-63.

43. Chuma J, Gilson L, Molyneux C: Treatment-seeking behaviour, cost burdens and coping strategies among rural and urban households in Coastal Kenya: an equity analysis. Trop Med Int Health 2007, 12(5):673-86.

44. Clinical signs that predict severe illness in children under age 2 months: a multicentre study. Lancet 2008, 371(9607):135-42.

45. Sehgal V, Sethi GR, Sachdev HP, Satyanarayana L: Predictors of mortality in subjects hospitalized with acute lower respiratory tract infections. Indian Pediatr 1997, 34(3):213-9.

Pre-publication history

The pre-publication history for this paper can be accessed here: http://www.biomedcentral.com/1471-2458/10/591/prepub

doi:10.1186/1471-2458-10-591

Cite this article as: Mwaniki et al:: An increase in the burden of neonatal admissions to a rural district hospital in Kenya over 19 years. BMC Public Health 2010 10:591.

\section{Submit your next manuscript to BioMed Central and take full advantage of:}

- Convenient online submission

- Thorough peer review

- No space constraints or color figure charges

- Immediate publication on acceptance

- Inclusion in PubMed, CAS, Scopus and Google Scholar

- Research which is freely available for redistribution

Submit your manuscript at www.biomedcentral.com/submit
Biomed Central 